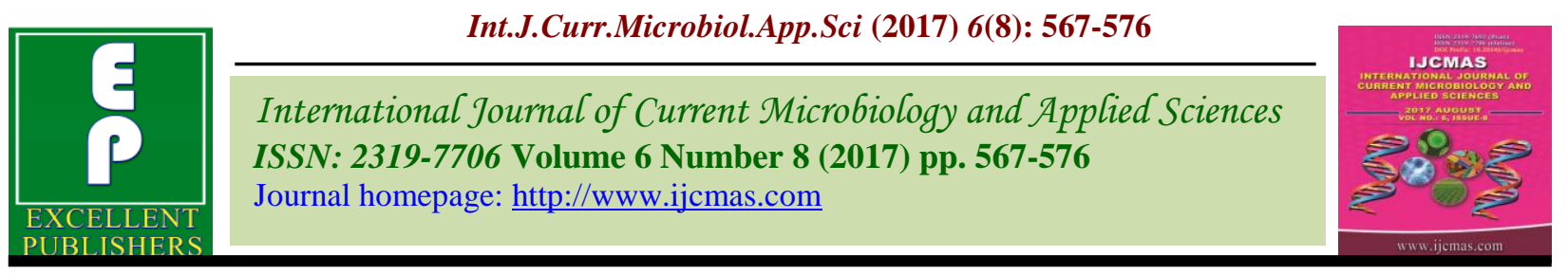

Original Research Article

https://doi.org/10.20546/ijcmas.2017.608.074

\title{
Combine Effects of Drought and High Temperature on Water Relation Traits in Wheat Genotypes under Late and Very Late Sown Condition
}

\author{
Kirpa Ram ${ }^{1 *}$, Renu Munjal ${ }^{2}$, Sunita $^{1}$ and Naveen Kumar ${ }^{2}$ \\ ${ }^{1}$ Department of Botany and Plant Physiology \\ ${ }^{2}$ Wheat and Barley Section, Department of Genetics and Plant Breeding \\ CCS Haryana Agricultural University, Hisar-125004 \\ *Corresponding author
}

\section{A B S T R A C T}

\begin{tabular}{|l|}
\hline Ke y w or d s \\
Wheat, \\
Drought, High \\
Temperature \\
and Water \\
Relation traits. \\
\hline Article Info \\
\hline Accepted: \\
04 June 2017 \\
Available Online: \\
10 August 2017 \\
\hline \hline
\end{tabular}

Combine effects of drought and high temperature, causes significant reduction in wheat (Triticum aestivum L.) quality and yield worldwide. The objective of this study was to quantify independent and combined effects of drought and high temperature stress in eight bread wheat genotypes at anthesis and 21 days after anthesis (DAA). To determine the effect of combine stress present experiment were conducted in randomized complete block design with five replications. In order to assess the relative capability of stress tolerance water relation parameters (relative water content, water potential and osmotic potential) and grain yield per plot were studied. Results of genotype $x$ environmental interaction showed grain yield reduction was significant under drought stress. Wheat genotypes showed significant reduction under terminal heat and drought stress condition, except DHTW-60 and C-306. The multiple statistical procedures used in this study showed that osmotic potential, water potential and grain yield is the most important trait for tolerant genotype selection. It is suggested that more emphasis should be given on the physiological characters for selecting wheat genotypes with higher grain yield under both (drought and high temperature) condition.

\section{Introduction}

Bread wheat (Triticum aestivum L.) is used mainly for human consumption and supports nearly $35 \%$ of the world population by providing $55 \%$ of the carbohydrates and $20 \%$ of the food calories consumed globally (Saleem, 2015). In India, 29\% of the total cultivable area faces drought condition out of which $10 \%$ is under severe drought (Singh and Vaishali, 2016). The response to stress depends on the wheat genotype, the specific temperature and the time in which the temperature regimen is imposed during the developmental programme (Ihsan et al.,
2016). Combine effect of high temperature and drought affect germination, tiller production, vegetative growth and dry matter production, reproductive development, grain yield (Boyer and Westgate, 2004; Prasad et al., 2008) and grain quality (Britz et al., 2007; Prasad et al., 2011). Combination of drought and high temperature stress alter physiological and molecular processes such as photosynthesis, accumulation of lipids, and transcript expression (Rizhsky et al., 2004), the combination had a significantly higher detrimental effect on growth and productivity 
of crops compared with each stress applied individually (Savin and Nicolas, 1996; Shah and Paulsen, 2003).

Drought and high temperature are a major constrain for wheat productivity in many regions of the world. Major abiotic stress in India that affects wheat is high temperature and drought. The abiotic stresses are estimated to reduce yields to less than a half of that possible under ideal growth conditions (Barnabas et al., 2008; Prasad et al., 2008).). Drought and high temperature not only affects the physiology but also affects the morphology, metabolism and biochemical properties of plants (Pandey et al., 2015).

These responses include stomatal closure, repression of cell growth and photosynthesis and activation of photorespiration. High temperature stress is a major yield limiting factor adversely affecting wheat development and growth and causes low yield in many regions of the world (Modarresi et al., 2010).

In India drought and high temperature usually occur simultaneously, high temperature and drought affect photosynthesis through disruptions in the structure and function of thylakoid membrane, reductions in chlorophyll content (Xu et al., 1995) and accelerate leaf senescence (Al- Khatib and Paulsen, 1984; Machado and Paulsen, 2001) whereas, drought affect osmotic adjustment in plants by increasing the rate of evapotranspiration and decline the rate of photosynthesis and increase photorespiration (Lawlor, 1979; Munjal and Dhanda, 2016).

The aim of present study was to investigate the independent and combined effects of drought and high temperature imposed from tillering to physiological maturity on water relation traits and grain yield of eight wheat genotypes under timely, late and very late sown condition.

\section{Materials and Methods}

\section{Raising of crop and plant material}

Two-year experiment was conducted during winter season of mid-November to April, 2015-16 and 2016-17 with eight selected wheat genotype viz., AKAW-3717, C-306, DHTW-60, HD-2967, HTW-11, Kundan, WH-730 and WH-1105. In control (irrigated) and drought-stressed experiments (with presowing irrigation only), genotypes were sown at optimum planting date, while for heatstressed experiment sowing date was delayed. Timely sowing was done on 17 November, 2015 and 13 November, 2016; late sowing on 14 December, 2015 and 16 December, 2016 and very late sowing 13 January, 2016 and 11 January, 2017. The experiment was conducted in the field and laboratory of Wheat and Barley section, Department of Genetics and Plant Breeding, College of Agriculture, CCS HAU, Hisar.

\section{Treatment detail}

Drought was created by withholding the irrigation at different stages (40 days after sowing (DAS), 80 DAS, 40+80 DAS (Both at 40 and 80 days after sowing) and for complete drought no irrigation was given throughout the year).

\section{Osmotic potential}

The leaf, which was used for water potential was frozen in a freezer below $-20{ }^{\circ} \mathrm{C}$ for seven days. The frozen leaf material was then thawed and cell sap extracted with the help of a syringe. $10 \mu \mathrm{l}$ of extracted cell sap was directly used for the determination of osmotic potential using an osmometer (Wescor 5520). Osmotic potential value obtained from the osmometer was in mmol kg-1, which was converted to - $\mathrm{MPa}$ (pressure unit) according to the equation: OP $(-\mathrm{MPa})=(-$ 
$\mathrm{R} \times \mathrm{T} \times$ osmometer reading)/1000; ( $\mathrm{R}$ is the gas constant (0.008314) and $\mathrm{T}$ is the laboratory temperature $(\mathrm{T}=298 \mathrm{~K})$.

\section{Water potential}

The fully expanded flag leaf of five plants of each treatment was used to determine the leaf water potential. The measurements were made from 8.00 to 10.00 a.m. with Scholander type pressure chamber (Model 3005. This pressure (-bar) was recorded as water potential in bar and the calculation for conversion of bar in $\mathrm{MPa}$ were done as following formula. $-10 \mathrm{bar}=1-\mathrm{Mpa}$.

\section{Relative water content}

The RWC was measured in flag leaf of five selected plant were weighed fresh $\left(\mathrm{W}_{\mathrm{F}}\right)$, floated on distilled water at room temperature in the dark for $4 \mathrm{~h}$, weighed again $\left(\mathrm{W}_{\mathrm{T}}\right)$, and finally dried at $80^{\circ} \mathrm{C}$ for $48 \mathrm{~h}$ for dry weight determination $\left(\mathrm{W}_{\mathrm{D}}\right)$. RWC was calculated according to the formula: RWC $(\%)=\left(\mathrm{W}_{\mathrm{F}^{-}}\right.$ $\left.\mathrm{W}_{\mathrm{D}}\right) /\left(\mathrm{W}_{\mathrm{T}}-\mathrm{W}_{\mathrm{D}}\right) \times 100$.

\section{Yield}

Grain yield was recorded after harvesting and thrashing the plot. The thrashed grains were cleaned and yield was recorded in gram.

\section{Sampling}

Five plants of each genotype were randomly tagged for each treatment. Samples for water relation traits were collected from the tagged plants at anthesis and 21 days after anthesis. Grain yield data were recorded at maturity.

\section{Results and Discussion}

The water status of a crop plant is usually expressed in terms of water content, water potential or/and some other water relation related components (Sabir et al., 2008; Javed et al., 2011).

\section{Osmotic potential (OP)}

Osmotic potential was significantly reduced at anthesis and 21 days after anthesis in all four treatments (D40, D80, D40+80 and Drought) and environments (LS and VLS), whereas genotype DHTW-60 and C-306 has shown maximum osmotic potential. At anthesis (Fig. 1a) mean osmotic potential value was -1.31 $\mathrm{MPa}$ in irrigated environment (timely sown), 1.50 $\mathrm{MPa}$ (late sown) and -1.55 $\mathrm{MPa}$ in (very late sown), combine effects of drought and heat showed mean osmotic potential value was $-1.75 \mathrm{MPa}$ in irrigated environment (timely sown), -1.92 MPa (late sown) and $2.13 \mathrm{MPa}$ plants whereas, at 21 days after anthesis (Fig. 1b) mean osmotic potential value was $-1.37 \mathrm{MPa}$ irrigated environment (timely sown), -1.55 MPa (late sown) and $1.71 \mathrm{MPa}$ in (very late sown), combine effects of drought and heat showed mean osmotic potential value was $-1.90 \mathrm{MPa}$ irrigated environment (timely sown), $-2.20 \mathrm{MPa}$ (late sown) and -2.51 MPa. All through there were significant difference in osmotic potential among the genotype and treatments, the interaction between genotype and treatment were significant in all three environments. Our results are in agreement with those of Siddique et al., (2000) and Akram, 2011 in wheat and Sharma et al., (2016) in barley found decrease in osmotic potential on the onset of stress.

\section{Water potential}

Water potential was significantly reduced at anthesis and 21 days after anthesis in all three treatments (Irrigated, D40, D80, D40+80 and Drought) and environments, whereas genotype DHTW-60 and C-306 has shown maximum water potential. 
Table.1 Grain yield per plot (g) in wheat genotypes under timely, late and very late sown conditions

\begin{tabular}{|c|c|c|c|c|c|c|c|c|c|c|c|c|c|c|c|c|c|c|}
\hline \multirow{3}{*}{ Genotype/ } & \multicolumn{6}{|c|}{ Timely Sown } & \multicolumn{6}{|c|}{ Late Sown } & \multicolumn{6}{|c|}{ Very Late Sown } \\
\hline & \multicolumn{6}{|c|}{ Treatments } & \multicolumn{6}{|c|}{ Treatments } & \multicolumn{6}{|c|}{ Treatments } \\
\hline & Control & D40 & D80 & D40+80 & Drought & Mean $(G)$ & Control & D40 & D80 & D40+80 & Drought & Mean $(G)$ & Control & D40 & D80 & $\mathrm{D} 40+80$ & Drought & Mean $(\mathbf{G})$ \\
\hline AKAW 3717 & 867.0 & 644.7 & 720.0 & 552.7 & 261.3 & 609.1 & 569.0 & 426.0 & 495.3 & 359.3 & 185.0 & 406.9 & 328.7 & 180.3 & 259.7 & 47.3 & 34.7 & 170.1 \\
\hline C-306 & 1067.7 & 696.3 & 816.3 & 628.7 & 404.0 & 722.6 & 704.0 & 486.0 & 553.3 & 417.0 & 333.3 & 498.7 & 524.7 & 247.0 & 318.0 & 110.3 & 88.7 & 257.7 \\
\hline DHTW-60 & 1237.3 & 706.0 & 830.0 & 638.7 & 448.0 & 772.0 & 796.0 & 492.0 & 559.0 & 425.3 & 353.7 & 525.2 & 534.0 & 249.7 & 324.3 & 118.0 & 95.3 & 264.3 \\
\hline HD-2967 & 912.3 & 666.3 & 747.7 & 565.0 & 273.3 & 632.9 & 586.3 & 443.7 & 515.0 & 389.3 & 247.3 & 436.3 & 347.7 & 203.7 & 278.7 & 71.7 & 54.7 & 191.3 \\
\hline HTW-11 & 945.3 & 688.0 & 793.7 & 601.7 & 367.3 & 679.2 & 652.0 & 477.7 & 536.3 & 411.3 & 325.0 & 480.5 & 494.3 & 231.3 & 317.0 & 99.0 & 80.0 & 244.3 \\
\hline WH-730 & 926.0 & 679.3 & 785.0 & 586.0 & 361.3 & 667.5 & 632.0 & 463.0 & 530.3 & 407.0 & 276.7 & 461.8 & 453.0 & 222.3 & 301.7 & 91.3 & 65.0 & 226.7 \\
\hline WH-1105 & 924.0 & 676.7 & 766.7 & 573.7 & 370.3 & 662.3 & 601.7 & 450.3 & 522.3 & 398.3 & 272.7 & 449.1 & 358.7 & 210.0 & 292.3 & 80.3 & 62.0 & 200.7 \\
\hline Mean (T) & 970.0 & 675.5 & 774.5 & 588.8 & 338.3 & & 639.8 & 459.5 & 526.3 & 397.5 & 273.8 & & 421.8 & 217.8 & 295.6 & 84.7 & 65.8 & \\
\hline \multirow{2}{*}{ CD at $5 \%$} & \multicolumn{3}{|c|}{ Treatment $(T)=10.00$} & \multirow{2}{*}{\multicolumn{3}{|c|}{$\mathrm{TxG}=28.29$}} & \multirow{2}{*}{\multicolumn{3}{|c|}{$\begin{array}{l}\text { Treatment }(\mathrm{T})=6.90 \\
\text { Genotype }(\mathrm{G})=8.73\end{array}$}} & \multirow{2}{*}{\multicolumn{3}{|c|}{$\mathrm{TxG}=19.52$}} & \multicolumn{3}{|c|}{ Treatment $(\mathrm{T})=3.89$} & \multirow{2}{*}{\multicolumn{3}{|c|}{$\mathrm{TxG}=10.99$}} \\
\hline & Genotype & $(\mathbf{G})=1$ & & & & & & & & & & & Genotype & $(G)=4$. & & & & \\
\hline
\end{tabular}


Fig.1a Osmotic potential (-MPa) in wheat genotypes at anthesis under timely, late and very late sown conditions

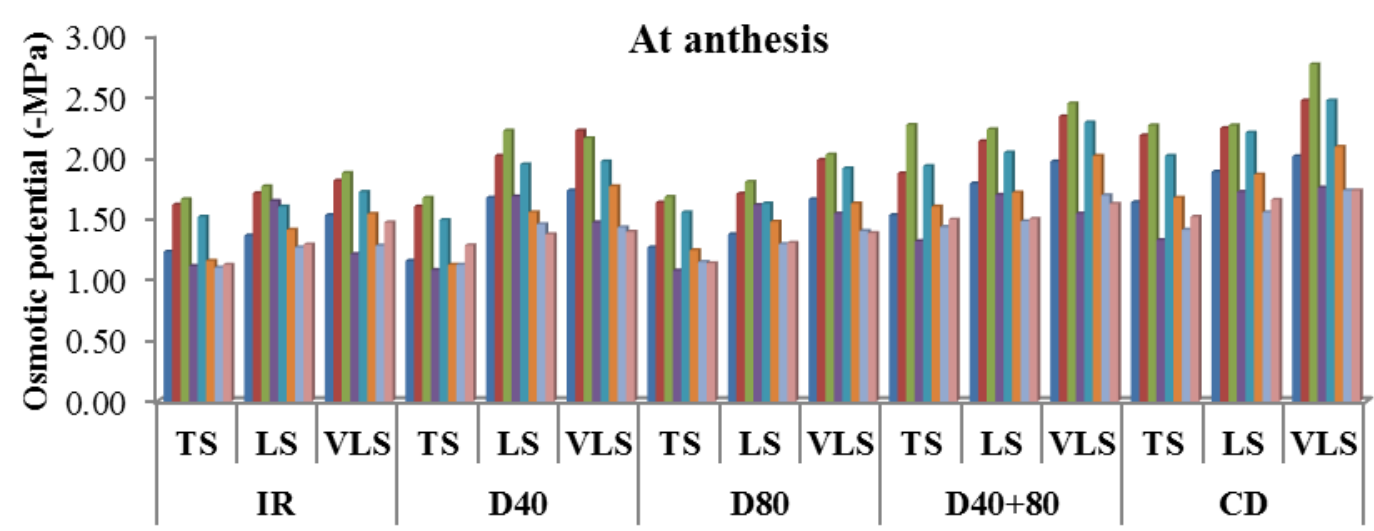

Time of application of drought

\begin{tabular}{|c|c|}
\hline $\begin{array}{l}\text { AKAW } 3717 \\
\text { HTW-11 }\end{array}$ & $\begin{array}{l}\text { C-306 } \\
\text { KUNDAN }\end{array}$ \\
\hline
\end{tabular}

IR- Irrigated, D40- Drought at 40 days after sowing (DAS), D80- Drought at 80 DAS, D40+80- Drought at 40+80 DAS, CD- Complete drought, TS-Timely Sown, LS-Late sown and VLS- Very Late Sown

Fig.1b Osmotic potential (-MPa) in wheat genotypes at 21 days after anthesis under timely, late and very late sown conditions

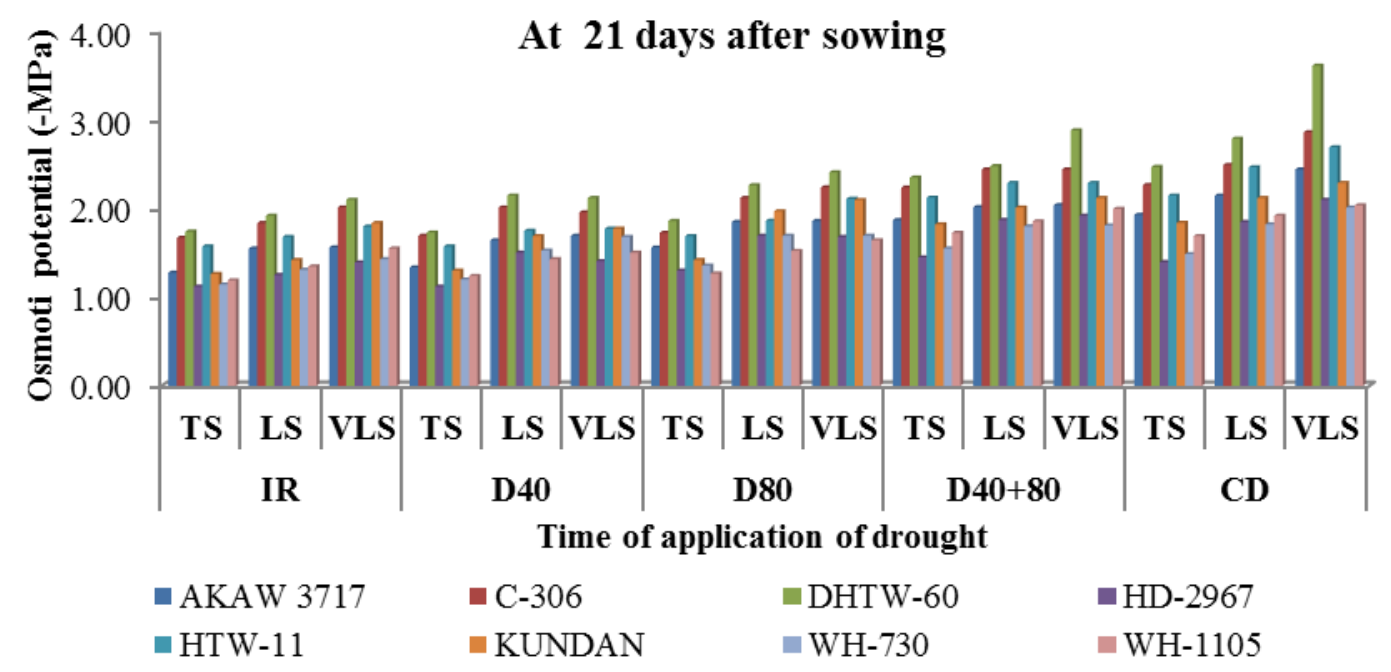

IR- Irrigated, D40- Drought at 40 days after sowing (DAS), D80- Drought at 80 DAS, D40+80- Drought at $40+80$ DAS, CD- Complete drought, TS-Timely Sown, LS-Late sown and VLS- Very Late Sown 
Fig.2a Water potential (-MPa) in wheat genotypes at anthesis under timely, late and very late sown conditions

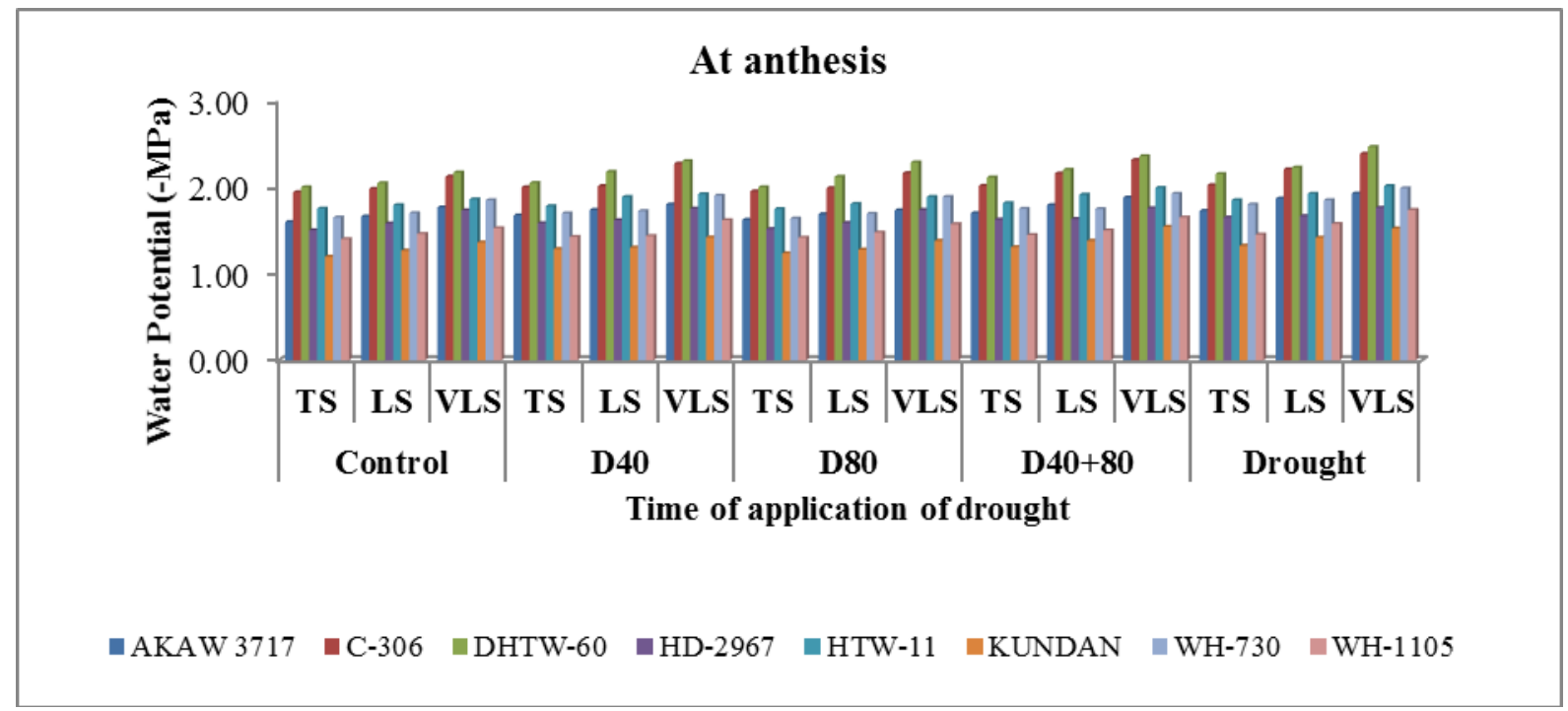

IR- Irrigated, D40- Drought at 40 days after sowing (DAS), D80- Drought at 80 DAS, D40+80- Drought at 40+80 DAS, CD- Complete drought, TS-Timely Sown, LS-Late sown and VLS- Very Late Sown

Fig.2b Water potential (-MPa) in wheat genotypes at 21 days after anthesis under timely, late and very late sown conditions

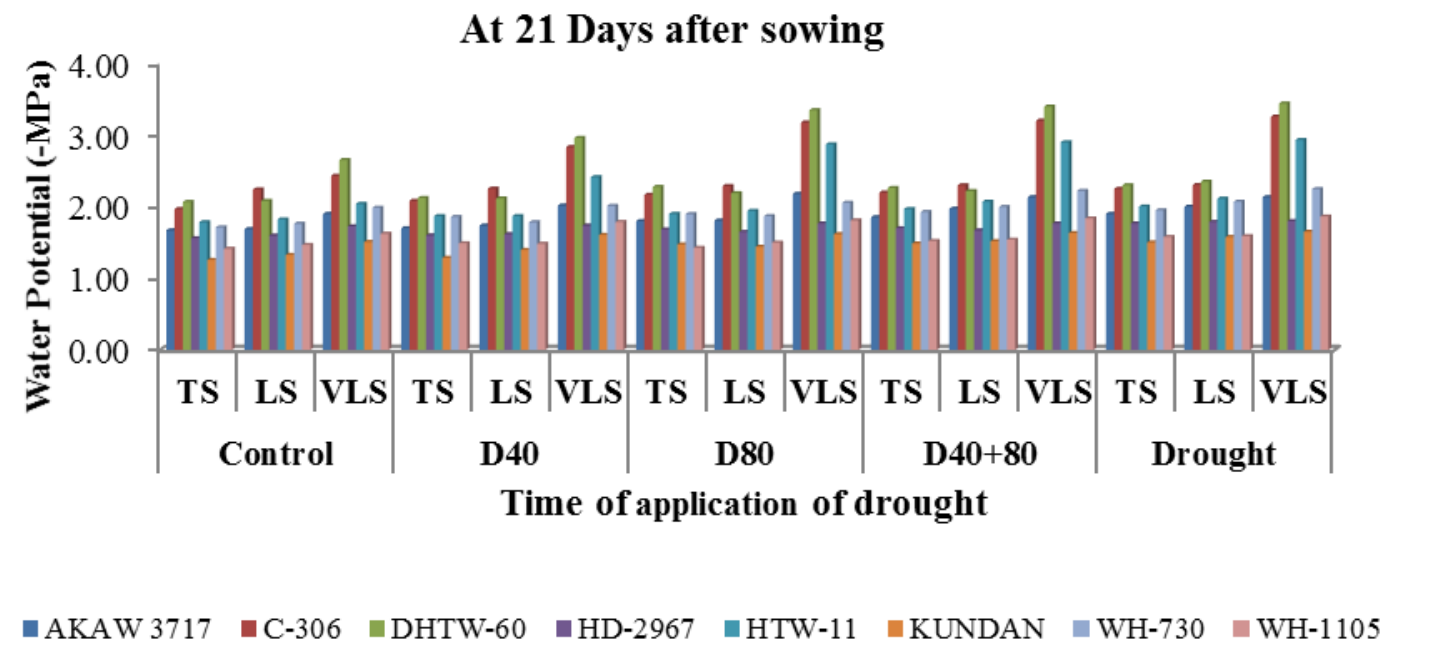

IR- Irrigated, D40- Drought at 40 days after sowing (DAS), D80- Drought at 80 DAS, D40+80- Drought at 40+80 DAS, CD- Complete drought, TS-Timely Sown, LS-Late sown and VLS- Very Late Sown 
Fig.3 Relative water content (\%) in wheat genotypes at anthesis and 21 days after anthesis under timely, late and very late sown conditions
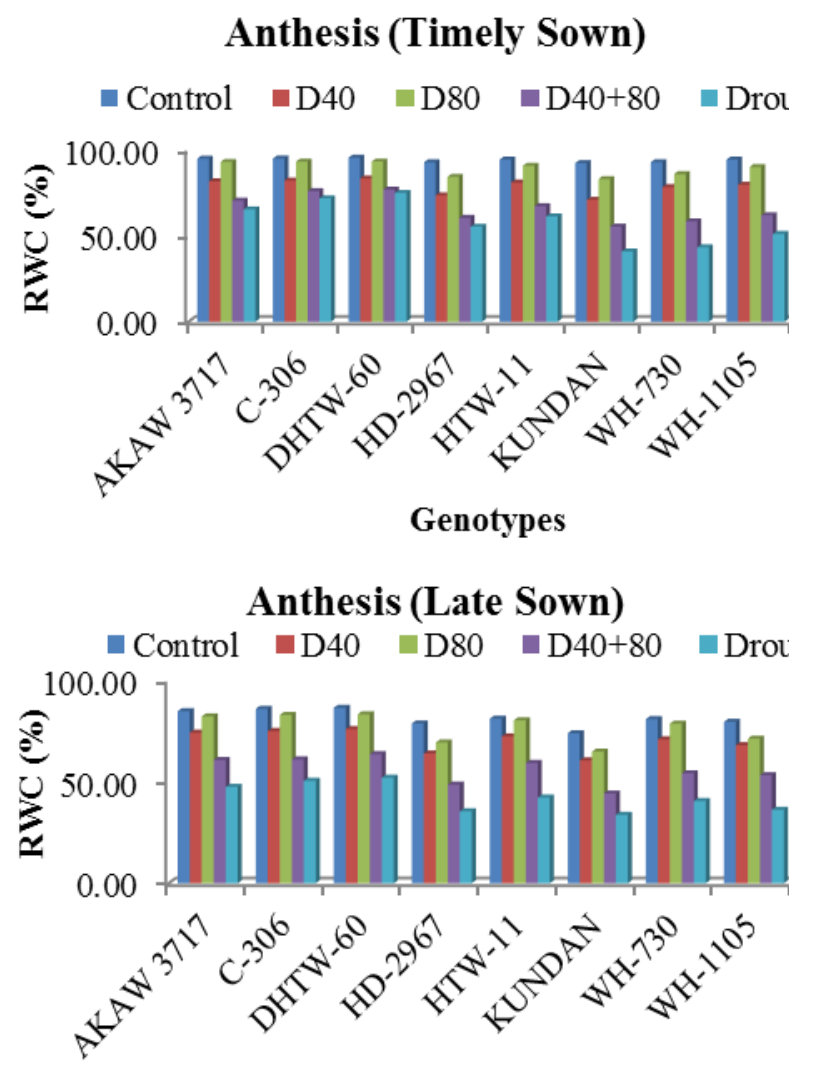

Genotypes

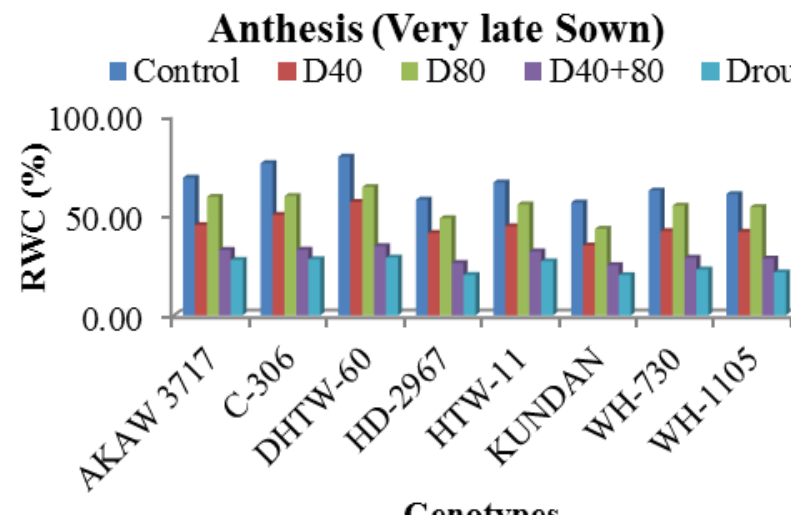

Genotypes

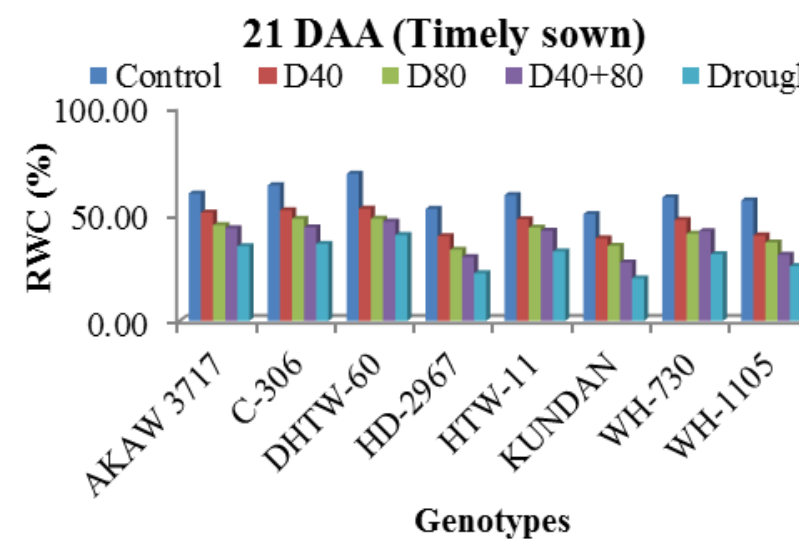

21 DAA (Late Sown)

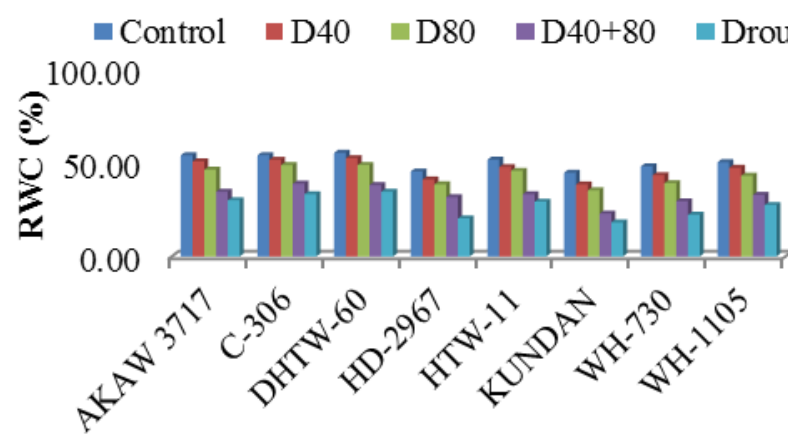

Genotypes

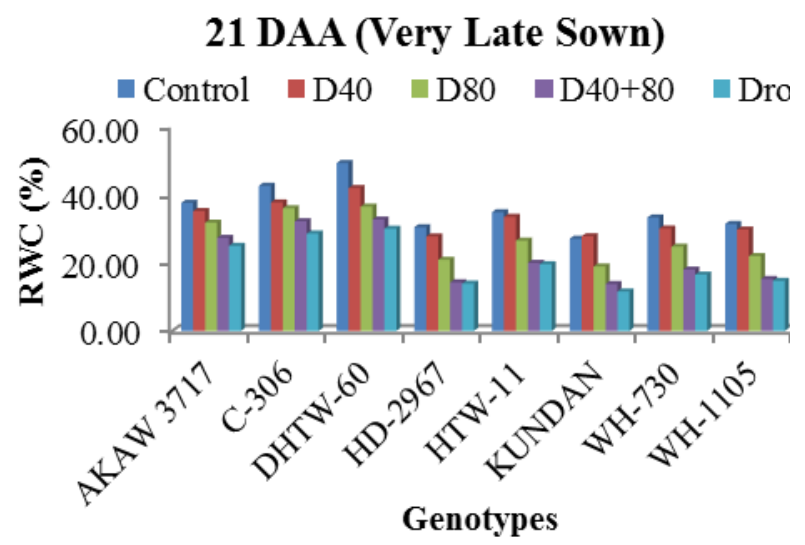

Control- Irrigated, D40- Drought at 40 days after sowing (DAS), D80- Drought at 80 DAS, D40+80- Drought at 40+80 DAS and Drought- Complete drought 
Drought stress at anthesis (Fig. 2a) showed mean water potential value was $-1.63 \mathrm{MPa}$ in irrigated environment (timely sown), -1.69 $\mathrm{MPa}$ (late sown) and $-1.80 \mathrm{MPa}$ in (very late sown), combine effects of drought and heat showed mean water potential value was -1.75 $\mathrm{MPa}$ in irrigated environment (timely sown), $1.84 \mathrm{MPa}$ (late sown) and $-1.98 \mathrm{MPa}$ in whereas, at 21 days after anthesis (Fig. 2b) showed mean water potential value was -1.68 $\mathrm{MPa}$ in irrigated environment (timely sown), 1.75 $\mathrm{MPa}$ (late sown) and -1.98 $\mathrm{MPa}$ in (very late sown), combine effects of drought and heat showed mean water potential value was $-1.91 \mathrm{MPa}$ in irrigated environment (timely sown), -1.97 $\mathrm{MPa}$ (late sown) and $-2.42 \mathrm{MPa}$ in. All through there were significant difference in water potential among the genotype and treatments, the interaction between genotype and treatment were significant in all three environments. Our results are in agreement with those of Abebe et al., (2003) in wheat, Behbahanizadeh et al., (2014) in barley genotypes water potential reduced in contrast to control condition and cultivars had a significant difference together in water relation traits.

\section{Relative water content (RWC)}

Relative water content indicated the relative amount of water present in the tissues, and is a measure of turgor in leaf tissue. All genotypes show higher RWC under timely sown irrigated conditions compared to late and very late sown stress condition in figure 3. Compared to 21 days after anthesis the relative water content was found higher at anthesis stage in tolerant and susceptible genotypes. As the duration of temperature and drought treatment increased the relative water content decreased in all genotypes at anthesis and 21 days after anthesis. Drought stress at anthesis showed mean relative water content value was $93.9 \%$ in irrigated environment (timely sown), $81.4 \%$ (late sown) and $66.0 \%$ in (very late sown). Combine effects of drought and heat showed mean relative water content value was $58.3 \%$ irrigated environment (timely sown), 50.6\% (late sown) and $35.8 \%$ whereas, at 21 days after anthesis shows mean relative water content value was $-57.9 \%$ in irrigated environment (timely sown), $42.3 \%$ (late sown) and $24.5 \%$ in (very late sown), combine effects of drought and heat showed mean relative water content value was $30.3 \%$ irrigated environment (timely sown), $27.0 \%$ (late sown) and 19.9\%. Genotype DHTW-60 and C-306 has sown high RWC as compare to other genotype under late and very late sown environment with drought condition. Decrease in RWC in response to abiotic stress has been documented in a wide variety of plants by Almeselmani et al., (2012); Saxena et al., (2014) and Ramani et al., (2017).

\section{Yield}

Overall average mean grain yield per plot was higher in DHTW-60 and C-306, followed by HTW-11 (Table 1). High temperature and drought led to a decrease in mean grain yield per plot, respectively. Interaction of genotype and treatments resulted in significant decrease of grain yield per plot, however maximum decline was observed at drought $40+80$ days after sowing and complete drought in late and very late sown condition. A greater decline in grain yield per plot was observed in AKAW3717 followed by HD-2967, due to interactive effects of combine stresses than DHTW-60 in relation to control in all environment. Our results are in agreement with those of Lopes et al., (2012) and Hossain (2012) in wheat found reduction in yield on the onset of stress. Under drought and heat stress conditions in cereal crops grain yield was positively correlated with RWC, WP and OP Behbahanizadeh et al., (2014).

In conclusion, from the above results and discussion, it may be concluded that the combined effect of high temperature and 
drought is more destructive than stress alone. Relative water content, osmotic potential and water potential decreased in wheat genotype under combine effects of drought and high temperature. Genotypes DHTW-60, C-306 and HTW-11 showed maximum water retention capacity and yield in all environment (timely sown, late sown and very late sown) and all treatments (drought at 40 DAS, drought at 80 DAS, Drought at $40+80$ DAS and complete drought) conditions. Genotype was found promising and may be exploited in future breeding programme in order to improve water status and ultimately yield in wheat crop.

\section{References}

Abebe, T., Guenzi, A.C., Martin, B. and Cushman, J.C. 2003. Tolerance of mannitolaccumulating transgenic wheat to water stress and salinity. J. Plant Physiol., 131: 1748-1755.

Akram, M. 2011. Growth and yield components of wheat under water stress of different growth stages. Bangladesh J. Agri. Res., 36: 455-468.

Al-Khatib, K., and Paulsen, G.M. 1990. Photosynthesis and productivity during hightemperature-stress of wheat genotypes from major world regions. J. Crop Sci., 30: 11271132.

Almeselmani, M., Saud, A., Al-Zubi, K., Abdullah, F., Hareri, F., Nassan, M., Ammar, M.A. and Kanbar, O. 2012. Physiological performance of different durum wheat varieties grown under rainfed condition. Global J. Sci. Frontier Res., 12: 55-63.

Barnabas, B., Jager, K. and Feher, A. 2008. The effect of drought and heat stress on reproductive processes in cereals. J. Plant Cell Environ., 31: 11-38.

Behbahanizadeh, S.A., Akbari, G.A., Shahbazi, M. and Alahdadi, I. 2014. Relations between barley root traits and osmotic adjustment under terminal drought stress. J. Agri. Sci., 6(7): 234-238.

Boyer, J.S., and Westgate, M.E. 2004. Grain yield with limited water. J. Experimental Bot., 55: 2385-2394.

Britz, S.J., Prasad, P.V.V., Moreau, R.A., Allen Jr, L.H., Kremer, D.F. and Boote, K.J. 2007. Influence of growth temperature on amounts of tocopherols, tocotrienols and c-ozyzanol in brown rice. J. Agri. Food Chem., 55: 7559-7565.

Hossain, A., Sarker, M.A.Z., Saifuzzaman, M., Hakim, M.A., Lozovskaya, M. V. and Zvolinsky, V.P. 2011. Effect of temperature on yield and some agronomic characters of spring wheat (Triticum aestivum L.) genotypes. Int. J. Agri. Res. Innovation Technol., 1(1\&2): 44-54.

Ihsan, M.Z., El-Nakhlawy, F.S., Ismail, S.M., Fahad, S., Daur, I. 2016. Wheat phenological development and growth studies as affected by drought and late season high temperature stress under arid environment. Frontier of Plant Sci., 49: 13-22.

Javed, N., Ashraf, M., Akram N.A. and AiQurainy, F. 2011. Alleviation of adverse effects of drought stress on growth and some potential physiological attributes in maize (Zea mays L.) by seed electromagnetic treatment. J. Photochem. Photobiol., 87: 1354-1362.

Lawlor, D.W. 1979. Effects of water and heat stress on carbon metabolism of plants with $\mathrm{C}_{3}$ and $\mathrm{C}_{4}$ photosynthesis. In: Stress Physiology in Crop Plants. Eds. H Mussel and RC Staples. Pp 304-326. John Wiley \& Sons, New York, NY.

Lopes, M.S., Reynolds, M.P., Jalal-Kamali, M.R., Moussa, M., Feltaous, Y., Tahir, I.S.A., Barma, N., Vargas, M., Mannes, Y. and Baum, M. 2012. The yield correlations of selectable physiological traits in a population of advanced spring wheat lines grown in warm and drought environments. J. Field Crop Res., 128: 129-136.

Machado, S. and Paulsen, G.M. 2001. Combined effects of drought and high temperature on water relations of wheat and sorghum. Plant Soil, 233: 179-187.

Modarresi, M., Mohammdi, V., Zali, A. and Mardi, M. 2010. Response of wheat yield and yield related traits of high temperature. Cereal Res. Communications, 38(1): 23-31.

Pandey, P., Ramegowda, V. and Senthilkumar, M. 
2015. Shared and unique responses of plants to multiple individual stresses and stress combinations: physiological and molecular mechanisms. Frontier Plant Sci., 6: 723-736.

Prasad, P.V.V., Pisipati, S.R., Momcilovic, I. and Ristic, Z. 2011. Independent and combined effects of high temperature and drought stress during grain filling on plant yield and chloroplast ef-tu expression in spring wheat. J. Agron. Crop Sci., 197: 430-441.

Prasad, P.V.V., Staggenborg, S.A. and Ristic, Z. 2008. Impacts of drought and/or heat stress on physiological, developmental, growth and yield processes of crop plants. In: L. H. Ahuja, L. Ma, and S. Saseendran, eds. Responses of Crops to Limited Water: Understanding and Modeling Water Stress Effects on Plant Growth Processes. Adv. Agri. Modeling Series, 1: 301-355.

Ramani, H.R., Mandavia, M.K., Dave, R.A., Bambharolia, R.P., Silungwe, H. and Garaniya, N.H. 2017. Biochemical and physiological constituents and their correlation in wheat (Triticum aestivum L.) genotypes under high temperature at different development stages. Int. J. Plant Physiology and Biochemistry. 9(1): 1-8.

Munjal, R. and Dhanda, S. 2016. Assessment of Drought Resistance in Indian Wheat Cultivars for Morpho-Physiological Traits. Ekin Journal of Crop Breeding and Genetics. 2(1): 74-81.

Rizhsky, L. H., Liang, H., Shuman, J., Shulaev, V., Davletova, S. and Mittler, R. 2004. When defense pathways collide: the response of Arabidopsis to a combination of drought and heat stress. Journal of Plant Physiology. 134: 1683-1696.

Sabir, P. and Ashraf, M. 2008. Intercultivar variation for salt tolerance in proso millet (Panicum miliaceum L.) at the germination stage. Pakistan Journal of Botany. 40: 677682.

Saleem, N., Ahmad, M., Vashnavi, R., Bukhari, A. and Ahmad Dar, Z. 2015. Stability analysis in Wheat: An application of additive main effects and multiplicative interaction. African Journal of Agricultural Research. 10(4): 295-300.

Savin, R., and Nicolas, M. E. 1996. Effect of short episodes of drought and high temperature on grain growth and starch accumulation of two malting barley cultivars. Australian Journal of Plant Physiology. 23: 201-210.

Saxena, J., Minaxi, Jha, A. 2014. Impact of a phosphate solubilising bacterium and an arbuscular mycorrhizal fungus (Glomus etunicatum) on growth, yield and $\mathrm{P}$ concentration in wheat plants. CLEAN-Soil, Air, Water, 42: 1248-1252.

Shah, N., and Paulsen, G.M. 2003. Interaction of drought and high temperature on photosynthesis and grain-filling of wheat. Plant Soil, 257: 219-226.

Sharma, K.D., Kumar, A. and Verma, S.R. 2016. Variations in physiological traits as screening tool for drought tolerance in barley (Hordeum vulgare L.). Indian J. Plant Physiol., 21(1): 93-100.

Siddique, M.R.B., Hamid, A. and Islam, M.S. 2000. Drought stress effects on water relations of wheat. Botanical Bull. Academia Sinica Taipei, 41: 35-39.

Singh, N.P. and Vaishali. 2016. Characterization of wheat (Triticum aestivum) for stay green trait. J. Appl. Natural Sci., 8(1): 107-111.

$\mathrm{Xu}$, Q., Paulsen, A.Q., Guikema, J.A. and Paulsen, G.M. 1995. Functional and ultrastructural injury to photosynthesis in wheat by high temperature during maturation. J. Environ. Experimental Bot., 35: 43-54.

\section{How to cite this article:}

Kirpa Ram, Renu Munjal, Sunita and Naveen Kumar. 2017. Combine Effects of Drought and High Temperature on Water Relation Traits in Wheat Genotypes under Late and Very Late Sown Condition. Int.J.Curr.Microbiol.App.Sci. 6(8): 567-576.

doi: https://doi.org/10.20546/ijcmas.2017.608.074 